\title{
Performa Dan Metabolit Darah Induk Kambing Bunting Yang Diberi Pakan Suplemen Selama Kebuntingan
}

\author{
Performance and Blood Metabolites of Pregnant Goats That Are Supplemented During \\ Pregnancy
}

Tati Murniati $^{1 *}$, Ahmad Muchlis ${ }^{1}$

*Email: tati.murniati16@gmail.com

${ }^{1}$ Program Studi Peternakan, Fakultas Pertanian, Universitas Bosowa

Diterima: 12 September 2021 / Disetujui: 24 Desember 2021

\begin{abstract}
ABSTRAK
Ketersediaan nutrisi pada induk baik melalui suplai dari makanan maupun hasil metabolisme induk mempunyai pengaruh sangat luas pada pertumbuhan fetus selama kebuntingan. Sangat diperlukan upaya perbaikan ketersediaan nutrisi melalui peningkatan sekresi endogen hormon metabolisme dan metabolit penting dan faktor-faktor pertumbuhan lainnya. Pengetahuan profil metabolik dapat berguna dalam memprediksi masalah metabolik. Penelitian ini dirancang mengikuti pola factorial 2 x 4 dengan 9 ulangan, sehingga jumlah kambing yang digunakan sebanyak 72 ekor induk kambing, yang terdiri dari kelompok kambing Peranakan Etawa dan kambing Kacang Pemberian pakan selama kebuntingan dibagi dalam 3 perlakuan induk bunting awal (umur kebuntingan 1 sampai 3 bulan), induk bunting akhir (umur kebuntingan 3 sampai 5 bulan), induk bunting tampa pemberian pakan suplemen dan Induk bunting dengan suplementasi selama kebuntingan. Pemberian pakan suplemen dapat meningkatkan pertambahan berat badan induk bunting. Waktu yang optimum pemberian pakan suplemen pada induk bunting memberikan pertambahan berat badan yang tinggi pada umur kebuntingan 1 sampai 3 bulan (awal). Kandungan glukosa darah dipengaruhi oleh jenis kambing dan umur kebuntingan. Kandungan glukosa darah tertinggi pada induk yang diberi pakan suplemen selama kebuntingan tetapi tidak berbeda pada kebuntingan awal dan akhir. Kandungan metabolit darah (urea dan kreatinine) tidak dipengaruhi oleh umur kebuntingan, dan kandungan metabolit darah relatif lebih tinggi pada ternak yang diberi pakan suplemen
\end{abstract}

Kata Kunci: Darah Induk, Kambing, Pakan, Bunting

\begin{abstract}
The availability of nutrients in the mother either through the supply of food or the results of the metabolism of the mother has a very broad influence on the growth of the fetus during pregnancy. It is necessary to improve the availability of nutrients by increasing the endogenous secretion of metabolic hormones and important metabolites and other growth factors. Knowledge of the metabolic profile can be useful in predicting metabolic problems. This study was designed to follow a $2 \times 4$ factorial pattern with 9 replications, so that the number of goats used were 72 mother goats, consisting of Etawa Peranakan goats and Kacang goats. 3 months), late pregnant women (gestational age 3 to 5 months), pregnant women without supplementation of feed and pregnant women with supplementation during pregnancy. Supplementary feeding can increase the weight gain of pregnant mothers. The optimum time of giving supplementary feed to pregnant mothers gives high weight gain at 1 to 3 months of gestation (early). Blood glucose content is influenced by the type of goat and gestational age. The blood glucose content was highest in broodstock fed supplements during pregnancy but did not differ in early and late pregnancy. The content of blood metabolites (urea and creatinine) was not affected by gestational age, and the content of blood metabolites was relatively higher in livestock fed supplementary diets.
\end{abstract}

Keywords: Blood, Goat, Feed, Pregnant

(c) (9) This work is licensed under Creative Commons Attribution License 4.0 CC-BY International license 


\section{A. PENDAHULUAN}

Makanan sebagai pengatur fungsi pertumbuhan dengan rendahnya kandungan nilai gizi makanan memegang peranan penting sehingga semua proses produksi akan mengalami gangguan atau terlambatnya proses tersebut. Kebutuhan nutrisi pada dasarnya pada kambing untuk semua breed adalah sama, baik pada jenis kelamin dan umur harus mengandung protein, energi, mineral dan vitamin.

Pengaturan nutrisi pada induk bunting telah mengimplikasikan pada perubahan pertumbuhan baik pada saat prenatal maupun postnatal mempengaruhi kesehatan den performans anak. Keterkaitan kebutuhan nutrisi induk terhadap berat lahir dan karakteristik fisik anak saat lahir dan status kesehatan. Kebutuhan nutrisi induk pada paruh pertama kebuntingan dan diikuti oleh nutrisi yang cukup dari pertengahaberat lahir anak memnghasilkan berat lahir normal. Kekurangan gizi awal janin mengakibatkan meningkatnya masalah kesehatan yang dialami oleh individu tersebut sampai dewasa. Pengaturan nutrisi dilakukan selama kebuntingan terutama selama dua dari trimester pertama (Caton and Hess, 2010). Perbedaan-perbedaan dalam kebutuhan nutrisi memerlukan modifikasi yang tepat dalam program pemberian makanan serta perubahan metabolik oleh induk untuk mendukung akhir kehamilan dan menyusui (Van Saun, 2013). Status nutrisi induk salah satu faktor program makanan terutama untuk pertumbuhan dan perkembangan dan fungsi sebagian besar organ (Caton and Hess, 2010).

Perbaikan selama kebuntingan adalah pendekatan pemberian nutrisi pada periode prenatal dengan tujuan pertumbuhan anak. Penyaluran nutrisi induk selama kebuntingan telah terbukti untuk program pertumbuhan dan perkembangan janin, baik selama dikandung dan kemudian kekehidupan dewasa Dimana saat pemeliharaan induk bunting membutuhkan lebih banyak protein dari pada energi (Pinkerton and Pinkerton, 2013). Kandungan protein dalam pakan ternak ruminansia sangat penting untuk meningkatkan kinerja produktif. Protein merupakan komponen mahal dari pakan ternak (Abdel-Ghani et al. 2011). Energi dan protein merupakan nutrisi utama yang dibutuhkan dalam jumlah besar dalam rangka mengoptimalkan reproduksi disisi lain, nutrisi tidak boleh over-fed karena hal ini juga dapat merusak reproduksi (Raj Bindari, et al. 2013). 
Lingkungan prenatal memiliki peran yang sangat besar dan sensitif terhadap berlangsungnya pertubuhan dan perkembangan janin baik selama kehidupan prenatal di dalam kandungan induknya tetapi berdampak pada pertumbuhan,perkebangan dan produksi Fluktuasi status pakan induk selama kebuntingan secara langsung berpengaruh terhadap myogenesis, adipogenesis dan fibrogenesis konseptus dalam kandungan. Pada tingkat molekuler bahwa jika terjadi fluktuasi status gizi dan energi dapat menyebabkan epigenetik dan berpontensi mejadi karakter yang diturunkan ke generasi selanjutnya (Rahardja, 2014).

Ketersediaan nutrisi pada induk baik melalui suplai dari makanan maupun hasil metabolisme induk mempunyai pengaruh sangat luas pada pertumbuhan fetus selama kebuntingan. Sangat diperlukan upaya perbaikan ketersediaan nutrisi melalui peningkatan sekresi endogen hormon metabolisme dan metabolit penting dan faktor-faktor pertumbuhan lainnya, pengukuran metabolit darah yaitu dengan melalui antara lain: Glukosa pada ruminansia digunakan sebagai sumber energi yang dapat memenuhi kebutuhan jaringan terutama ruminansia. Selain untuk energi, glukosa penting untuk pemeliharaan sel- sel tubuh terutama darah dan syaraf, perkusor berbagai komponen sel, pembentukan beberapa komponen air susu.

Pada masa kebuntingan kadar glukosa darah merupakan indikasi tingkat energi hewan. Hasil penelitian ini menunjukkan pula kadar glukosa berhubungan dengan penuaan kambing (Bulent Elitok, 2012).

Hasil Penelitian Irkham Widiyono, dkk. (2013) menunjukkan bahwa pembatasan pakan sampai sekitar $50 \%$ dari komsusi pakan adlibitum (80\% dari kebutuhan maintenance) dapat mengakibatkan perubahan beberapa parameter kimia darah yang terkait dengan status metabolisme kambing Peranakan Etawa akhir periode pakan terbatas kadar fosfatanorganik, kreatinin, nitrogen urea darah dan kolesterol mengalami peningkatan yang signifikan sebaliknya kadar glukosa, kalsium dan trigliserida juga mengalami penurunan yang signifikan. Urea Darah Blood urea nitrogen adalah tehnik pengukuran yang dapat digunakan untuk mengukur status protein dan energy secara biologis. Blood urea nitrogen dapat digunakan untuk mengukur status nutrisi pada ternak (Hammond, 1998). Kreatinine merupakan produk sisa dari perombakan keratin 
fosfat yang terjadi di otot. Melalui pengukuran kreatinine, jumlah protein yang ada dalam tubuh dapat diestimasi, karena kandungan kreatinine dalam urin berkorelasi positif dengan protein tubuh. Nilai rata-rata kreatinine adalah 94,97 \pm $2.90 \mu \mathrm{mol} / 1$ yang diperoleh yang diperoleh terlepas dari jenis kelamin dan umur. Nilai kisaran adalah 55- $153 \mu \mathrm{mol} / \mathrm{l}$. Nilai normal konstituen darah dapat dipengaruhi oleh umur, jenis kelamin, ras, gizi dan faktor lainnya. Kreatinine tidak mengalami reaksi katabolik selain dekomposisi kreatinine (Gottam, et al. 2005).

\section{B. METODE PENELITIAN \\ 1. Tempat dan Waktu}

Penelitian berlangsung selama lima bulan kebuntingan induk kambing peranakan Etawa dan Kacang. Tempat penelitian dilakukan di Kecamatan Tamalatea, Kabupaten Jeneponto pada pada peternakan rakyat. Pemeriksaan sampel darah di Balai besar labaoratorium kesehatan Dinas Kesehatan Provinsi Sulawesi Selatan

\section{Alat dan Bahan}

Ternak yang digunakan pada penelitian ini adalah kambing milik peternak di kabupaten Jeneponto. Ternak diberi pakan suplemen dan ransum basal yang terdiri dari rumput potongan, daun gamal, tanaman sisa-sisa hasil pertanian dan ampas tahu yang diberikan secara adlbitum dan pakan suplemen 200 gr/ekor/hari.

Pembuatan pakan suplemen dengan Urea Molases Multinutrient Block (UMMB) dengan kandungan protein 10\%. Pakan suplemen terbuat dari urea, dedak padi, molasses, mineral mix, bungkil kelapa, tepung bulu, semen, garam, limbah digister dan kapur yang diproses dalam bentuk nutrient block dan cetakan UMMB. Pemberian pakan suplemen UMMB diberikan secara adlibitum

Induk kambing dibagi kedalam 2 kelompok bangsa kambing dan dibagi kedalam perlakuan induk berdasarkan status kebuntingan, dengan perlakuan waktu pemberian pakan suplemen dalam ransum

Penelitian ini dirancang mengikuti pola factorial $2 \times 4$ dengan 9 ulangan, sehingga jumlah kambing yang digunakan sebanyak 72 ekor induk kambing, yang terdiri dari kelompok kambing Peranakan Etawa dan kambing Kacang.

Pada tahun pertama perlakuan pemberian pakan nutrition in utero. Induk kambing bunting dibagi dalam 3 perlakuan : 
U1 : induk bunting awal (umur kebuntingan 1 sampai 3 bulan)

U2 : induk bunting akhir (umur kebuntingan 3 sampai 5 bulan)

U3 : induk bunting tampa pemberian pakan suplemen.

U4 : induk bunting dengan suplementasi selama kebuntingan

Tabel 1. Susunan Pakan Suplemen

\begin{tabular}{llc}
\hline 1. & Dedak & $24 \%$ \\
2. & Molasses & $30 \%$ \\
3. & Mineral mix & $2 \%$ \\
4. & Bungkil kelapa & $10 \%$ \\
5. & Tepung bulu & $12 \%$ \\
6. & Semen & $5 \%$ \\
7. & Garam & $5 \%$ \\
8. & Tepung coklat & $5 \%$ \\
9. & Urea & $7 \%$ \\
\hline & Total & $100 \%$ \\
\hline & Selama penelitian & ternak akan
\end{tabular}

ditempatkan dalam kandang untuk setiap individu, dan diberi ransum. Parameter yang akan diukur dalam penelitian pertambahan berat badan induk dan metabolit darah: Glukosa,Urea dan Kreatinine

Data diolah dengan SPSS 20. Induk kambing bunting dibagi ke dalam 2 kelompok induk kambing Kacang dan induk kambing peranakan Etawa, sesuai dengan perlakuan pemberian pakan selama kebuntingan.

\section{HASIL DAN PEMBAHASAN}

1. Pertambahan Berat badan Induk Bunting

Pemberian pakan suplemen UMMB pada induk kambing bunting pada kambing Peranakan Etawa dan kambing Kacang yang diberikan pada waktu umur kebuntingan yang berbeda di tampilkan pada tabel 1, memperlihatkan rata-rata pertambahan berat badan induk yang berbeda untuk setiap umur kebuntingan.

Tabel 2. Rata-rata Pertambahan Berat

\begin{tabular}{lcccc}
\multicolumn{5}{c}{ Badan Induk (kg/hari) } \\
\cline { 2 - 5 } $\begin{array}{l}\text { Jenis } \\
\text { Kambing }\end{array}$ & $\mathrm{U} 1$ & Waktu Pemberian Pakan Suplemen \\
& & $\mathrm{U} 2$ & $\mathrm{U} 3$ & $\mathrm{U} 4$ \\
\hline $\begin{array}{l}\text { Peranakan } \\
\text { Etawa } \\
\text { Kacang }\end{array}$ & $0.2174 \pm .0 .6788^{\mathrm{a}}$ & $0.2144 \pm .067026^{\mathrm{a}}$ & $0.11500 \pm .058877^{\mathrm{b}}$ & $0.2102 \pm .101041^{\mathrm{a}}$ \\
\cline { 2 - 5 } & $0.1107 \pm .04987^{\mathrm{a}}$ & $0.1848 \pm .233836^{\mathrm{b}}$ & $0.08344 \pm .03443^{\mathrm{a}}$ & $0.13689 \pm 0.5129^{\mathrm{a}}$ \\
\hline
\end{tabular}
Keterangan: huruf berbeda pada baris yang sama menujukkan perbedaan $(\mathrm{p}<0.05)$

Hasil ini menunjukkan bahwa waktu pemberian pakan suplemen UMMB berpengaruh terhadap pertambahan berat badan induk bunting, pemberian pakan suplemen memberikan hasil yang efektif dapat meningkatkan berat badan induk kambing. Suplementasi UMMB secara keseluruhan dapat memberikan pengaruh melalui peningkatan protein mikrobial, peningkatan daya cerna, peningkatan konsumsi pakan hingga diperoleh keseimbangan yang lebih baik antara asam amino dan energi di dalam zat-zat nutrisi yang terserap. Nutrisi memainkan peran utama pada peningkatan efisiensi reproduksi pada semua ternak. Energi 
dan protein merupakan nutrisi utama yang dibutuhkan dalam jumlah besar dalam rangka mengoptimalkan reproduksi disisi lain, nutrisi tidak boleh over-fed karena hal ini juga dapat merusak reproduksi (Raj Bindari, et al. 2013).

Waktu pemberian suplemen pada induk bunting memberikan peningkatan pertambahan berat badan yang lebih tinggi dibandingkan pada ternak kambing yang tidak diberi UMMB (U3). Waktu pemberian suplemen UMMB berpengaruh $(\mathrm{P}<0.05)$ terhadap pertambahan berat badan yang lebih tinggi pada kedua bangsa kambing baik PE maupun kambing Kacang, dimana waktu pemberian kelompok kebuntingan awal (umur kebuntingan 1 sampai 3 bulan) kemudian diikuti oleh kelompok kebuntingan akhir (3 sampai 5 bulan) dan kelompok yang diberi pakan suplemen selama masa kebuntingan (1 sampai 5 bulan).

Hasil ini menunjukkan bahwa waktu pemberian pakan suplemen UMMB efektif dapat meningkatkan berat badan induk kambing bunting. Pertumbuhan prenatal dipengaruhi secara langsung dan tidak langsung dari asupan pakan induk dari tahap awal kehidupan embrio, saat kebutuhan gizi untuk pertumbuhan konseptus dan saat kebutuhan gizi tidak terpenuhi maka pertumbuhan akan memberikan dampak negative pada efisiensi pertubuhan postnatal dan pertumbuhan komposisi tubuh (Larson, et.al. 2009). Pemberian suplemen pada kambing di Philipina pada umur 4 bulan meningkatkan pertambahan berat badan $54,8 \mathrm{gr} / \mathrm{ekor} / \mathrm{hari}$ sedang yang tidak diberi konsentrat 16,1 gr/ekor/hari (Hayashida, dkk. 2004).

Pemberian suplemen pada kelompok U1 dengan kebuntingan umur 1 sampai 3 bulan (kebuntingan awal) menghasilkan pertambahan berat badan yang lebih tinggi dari kelompok U2 dan U4 ini memperlihatkan bawah kebutuhan pakan suplemen telah mencukupi untuk memenuhi kebutuhan nutrisi induk selama masa awal kebuntingan. Kebutuhan nutrisi induk pada masa kebuntingan ditentukan oleh kesimbangan metabolisme dalam darah dengan adanya keseimbangan nutrisi ransum (Rahardja, 2003). Direkomendasikan bahwa kebutuhan nutrisi trisemester pertama lebih banyak 1,5 kali pada sapi perah dan sapi potong sedang pada domba 2,2 kali lebih banyak pada induk yang beranak tiga dibandingkan yang beranak tunggal dan apabila kecukupan nutrisi tidak terpenuhi pada masa kebuntingan maka tidak optimalnya potensi genetik 
pertumbuhan anak tersebut. Status nutrisi induk salah satu faktor pengaturan nutrisi terutama untuk pertumbuhan dan perkembangan dan fungsi sebagian besar organ selama kebuntingan (Caton and Hess, 2010). Dimana saat pemeliharaan induk bunting membutuhkan lebih banyak protein dari pada energi (Pinkerton and Pinkerton, 2013). Lingkungan prenatal memiliki peran yang sangat besar dan sensitif terhadap berlangsungnya pertubuhan dan perkembangan janin baik selama kehidupan prenatal di dalam kandungan induknya tetapi berdampak pada pertumbuhan,perkebangan dan produksi Fluktuasi status pakan induk selama kebuntingan secara langsung berpengaruh terhadap myogenesis, adipogenesis dan fibrogenesis konseptus dalam kandungan. Pada tingkat molekuler bahwa jika terjadi fluktuasi status gizi dan energi dapat menyebabkan epigenetik dan berpontensi mejadi karakter yang diturunkan ke generasi selanjutnya (Rahardja, 2014).

\section{Metabolit Darah (Glukosa, Urea dan Kreatinine)}

Ketersediaan nutrisi pada induk baik melalui suplai dari makanan maupun hasil metabolisme induk mempunyai pengaruh sangat luas pada pertumbuhan fetus selama kebuntingan. Sangat diperlukan upaya perbaikan ketersediaan nutrisi melalui peningkatan sekresi endogen hormon metabolisme dan metabolit penting dan faktor-faktor pertumbuhan lainnya, pengukuran metabolit darah yaitu dengan melalui antara lain:

\section{Glukosa}

Glukosa pada ruminansia digunakan sebagai sumber energi yang dapat memenuhi kebutuhan jaringan terutama ruminansia. Selain untuk energi, glukosa penting untuk pemeliharaan sel-sel tubuh terutama darah dan syaraf, perkusor berbagai komponen sel, pembentukan beberapa komponen air susu pada hewan berlaktasi. Rata-rata glukosa darah pada kedua jenis kambing tertera pada Tabel 3. Tabel 3. Rata-rata Glukosa (mg/dl) darah Induk berdasarkan Status Kebuntingan Induk

\begin{tabular}{lcccc}
\hline Jenis & \multicolumn{4}{c}{ Waktu Pemberian Pakan Suplemen } \\
\cline { 2 - 5 } Kambing & $\mathrm{U} 1$ & $\mathrm{U} 2$ & $\mathrm{U} 3$ & $\mathrm{U} 4$ \\
\hline Peranakan & $49.56 \pm 5.053^{\mathrm{a}}$ & $50.33 \pm .6 .124^{\mathrm{a}}$ & $44.33 \pm .3 .640^{\mathrm{b}}$ & $59.00 \pm 4.123^{\mathrm{c}}$ \\
\cline { 2 - 5 } Etawa & $49.33 \pm 5.723^{\mathrm{a}}$ & $49.22 \pm 4.944^{\mathrm{a}}$ & $.42 .00 \pm 5.000^{\mathrm{b}}$ & $48.78 \pm 5.094^{\mathrm{c}}$ \\
Kacang & & & &
\end{tabular}

Keterangan: huruf berbeda pada baris yang sama menujukkan perbedaan $(\mathrm{p}<0.05)$

Hasil penelitian menunjukkan bahwa jenis kambing dan waktu peberian pakan suplemen UMMB pada induk bunting memperlihatkan pengaruh nyata ( $\mathrm{P}<0.05)$ terhadap kandungan glukosa darah induk, dimana kandungan glukosa darah lebih tinggi pada kambing Peranakan Etawa dibanding kabing Kacang. Hasil ini berbeda dengan Irkham 
Widiyono dan Sarmin, (2011) Konsentrasi metabolit darah kambing PE lebih rendah dibandingkan dengan nilai yang ada pada literature untuk ruminansia kecil lain. pH darah, bicarbonate, pCO2, BUN dan glukosa tidak menunjukkan perubahan signifikan. Konsentrasi total protein, globulin dan kreatinine pada hewan muda secara signifikan lebih rendah dibanding dengan hewan dewasa kambing Peranakan Etawa yang ada di Indonesia.

Waktu pemberian pakan suplemen UMMB memperlihatkan bahwa pemberian pakan suplemen selama kebuntingan memperlihatkan kandungan glukosa darah yang lebih tinggi dari pada yang diberikan pada umur kebuntingan awal (U1) dan kebuntingan akhir (U2) sedangkan pada induk bunting yang tidak diberi pakan suplemen memperlihatkan kandungan glukosa darah yang paling rendah pada kedua bangsa kambing.

Pengetahuan profil metabolik dapat berguna dalam memprediksi masalah metabolik. Pada masa kebuntingan kadar glukosa darah merupakan indikasi tingkat energi hewan (Bulent Elitok, 2012). Kadar glukosa darah di bawah nilai normal pada musim hujan . Kadar glukosa darah secara signifikan dipengaruhi oleh musim (Barakat and ElGuindi, 2010).

Induk yang diberi pakan suplemen selama kebuntingan terlihat kandungan glukosa darahnya cenderung lebih tinggi, hal ini menunjukkan bahwa pakan suplemen member energy yang cukup selama induk bunting dan kebutuhannya telah tercukupi. Hasil Penelitian Irkham Widiyono, dkk. (2013) menunjukkan bahwa jika terjadi pembatasan pakan sampai sekitar $50 \%$ dari komsusi pakan adlibitum $\quad(80 \%$ dari kebutuhan maintenance) dapat mengakibatkan perubahan beberapa parameter kimia darah yang terkait dengan status metabolisme kambing Peranakan Etawa akhir periode pakan terbatas kadar fosfatanorganik, kreatinin, nitrogen urea darah dan kolesterol mengalami peningkatan yang signifikan sebaliknya kadar glukosa, kalsium dan trigliserida juga mengalami penurunan yang signifikan.

\section{Urea}

Blood urea nitrogen dapat digunakan untuk mengukur status nutrisi pada ternak. Urea adalah produk alami dari metabolisme pada kambing dan ruminansia lainnya. Urea merupakan sumber nitrogen yang digunakan untuk sintesis protein dalam saluran pencernaan. 
Konsentrasi urea dalam darah umumnya ditafsirkan sebagai indikasi pemanfaatan asam amino lebih efisien (Cronje, 1992). Apabila terjadi kekurangan enegi maka protein akan berlebihan dan tidak dapat dimanfaatkan oleh mikroba rumen kelebihan konsumsi protein kasar dapat meningkatkan konsentrasi urea dalam plasma.

Kandungan urea dalam darah pada kedua jenis kambing: Peranakan Etawa dan kambing Kacang dengan pemberian pakan suplemen UMMB tidak memperlihatkan pengaruh pada urea dalam darah, begitu pula dengan waktu pemberian pakan suplemen pada kedua bangsa kambing. Rata-rata kandungan urea dalam darah terdapat Tabel 4.

Tabel.4. Rata-rata Kandungan Urea Darah (mg/dl) Induk

\begin{tabular}{lcccc}
\hline \multirow{2}{*}{ Jenis } & \multicolumn{4}{c}{ Waktu Pemberian Pakan Suplemen } \\
\cline { 2 - 5 } Kambing & U1 & U2 & U3 & U4 \\
\hline Peranakan & $33.11 \pm .13 .541$ & $34.67 \pm .11 .769$ & $29.44 \pm .5 .053$ & $36.44 \pm .6 .747$ \\
\cline { 2 - 5 } Etawa & $35.00 \pm .11 .885$ & $31.33 \pm 11.597$ & $.28 .67 \pm 8.789$ & $32.11 \pm 3.018$ \\
Kacang & & & & \\
\hline
\end{tabular}

Nilai kisaran kandungan urea darah hasil penelitian pada kedua jenis kambing rata-rata antara 28.67 - $36.44 \mathrm{mg} / \mathrm{dl}$, dari tabel di atas terlihat bahwa kandungan urea kambing peranakan Etawa cenderung lebih tinggi dibanding kambing Kacang. Begitupula pada pada tingkat pemberian pakan suplemen pada induk yang diberi suplemen selama kebuntingan, lalu diikuti dengan induk yang diberi pakan suplemen pada kebuntingan akhir (3 sampai 5 bulan), kemudian diikuti pada awal kebuntingan sedangkan induk yang tidak diberi pakan suplemen kandungan urea darahnya lebih rendah.

Pada induk yang diberi pakan suplemen terlihat kandungan urea darah lebih tinggi dibanding tampa pemberian dari semua umur kebuntingan. Kadar urea darah pada kambing yaitu antara 2938 mg/dl (Fachiroh dkk. 2012) sedangkan Manu (2007). Kadar urea darah yang normal pada ternak kambing 13-44 mg/dl. Kisaran urea darah kambing penelitian terlihat masih dalam kisaran kandungan urea darah normal.

Keseimbangan nitrogen dan kadar urea darah merupakan indikator yang sering digunakan untuk mengetahui efektivitas metabolisme protein pakan yang dikonsumsi oleh ternak ruminansia. Data keseimbangan nitrogen secara umum menunjukkan status nutrien pakan ternak. Oleh karena itu keseimbangan nitrogen adalah suatu cara untuk mengukur metabolism protein di dalam tubuh. Imbangan nitrogen dapat dipakai untuk menentukan kebutuhan protein guna keperluan pertumbuhan. Dimana takaran minimal protein yang memberj retensi maksimal untuk pertumbuhan ternak dalam prinsif imbangan nitrogen ini 
adalah kebutuhan protein bagi ternak yang bersangkutan (Tillman et al., 2005).

\section{Kreatinine}

Kreatinine merupakan produk sisa dari perombakan keratin fosfat yang terjadi di otot. Melalui pengukuran kreatinine, jumlah protein yang ada dalam tubuh dapat diestimasi, karena kandungan kreatinine dalam urin berkorelasi positif dengan protein tubuh. Rata-rata kandungan kreatinine induk bunting berdasarkan pemberian pakan suplemen pada kambing penelitian tertera pada Tabel 5.

Tabel 5. Rata-Rata Kandungan Kreatinine (mg/dl) Darah Induk \begin{tabular}{lcccc}
\hline Jenis & \multicolumn{4}{c}{ Waktu Pemberian Pakan Suplemen } \\
\cline { 2 - 5 } Kambing & U1 & U2 & U3 \\
\hline Peranakan & $0.7344 \pm 0.2392$ & $0.8356 \pm 0.2900$ & $0.6156 \pm 0 . .2512$ & $0.6700 \pm 0.2191$ \\
\cline { 2 - 5 } Etawa & $1.0156 \pm 0.93283$ & $0.7344 \pm 0.28465$ & $.0 .5578 \pm 0.30817$ & $0.5122 \pm .0 .7546$ \\
\hline Kacang & & &
\end{tabular}

Nilai rata-rata kreatinine adalah $0.5122-1.0156 \mathrm{mg} / \mathrm{dl}$ yang diperoleh terlepas dari jenis bangsa kambing dan umur kebuntingan induk. Nilai rujukan untuk kadar kreatinine normal $0.60-1.20$ $\mathrm{mg} / \mathrm{dl}$.

Hasil penelitian memperlihatkan bahwa bangsa dan waktu pemberian pakan suplemen pada induk bunting tidak memperlihatkan pengaruh yang nyata terhadap kandungan kreatinine darah. Tetapi terlihat bahwa pemberian pakan suplemen memperlihatkan kecenderungan kandungan kreatinine yang lebih tinggi, terutama pada kebuntingan awal pada kambing Kacang dan kebuntingan akhir pada kambing PE. Kadar kreatinin yang tinggi pada hewan dewasa berkorelasi dengan metabolisme protein yang terkait dengan massa otot (Bulent Ellitok, 2012).

Nilai normal konstituen kreatinine darah dapat dipengaruhi oleh umur, jenis kelamin, ras, gizi dan faktor lainnya. Kreatinine tidak mengalami reaksi katabolik selain dekomposisi kreatinine (Gottam, et al. 2005). Sedangkan menurut De Campeneere et al (2000) menyimpulkan bahwa ekresi kreatinine setiap hari tidak dipengaruhi oleh konsumsi protein. Kadar kreatinin meningkat pada kambing pada umur tua tetapi kadar urea lebih tinggi pada kambing muda dari pada kambing dewasa. Sebagian besar dari kambing memiliki kadar kreatinin di bawah nilai normal pada kedua musim tetapi tingkat yang lebih tinggi dalam kering dari pada dimusim hujan (Barakat and El-Guindi, 2010). Pada kambing Mawari hasil penelitian Sharma and Puri (2013) kedua jenis kelamin kambing pada umur 0-3 tahun yang diukur selama iklim panas dan moderat. Nilai rata-rata keseluruhan $(\mathrm{mg} / \mathrm{dl})$ kreatinine $0,73 \pm 0,02 \mathrm{mg} / \mathrm{dl}$. Iklim berpengaruh terhadap kreatinine serum, jenis kelamin kambing jantan menunjukkan nilai yang lebih tinggi 
dibanding betina. Nilai rata-rata serum kreatinine secara signifikan lebih tinggi selama musim panas dan tidak berbeda selama periode suhu dingin dibanding dengan rata-rata moderat secara keseluruhan. Dalam setiap periode suhu lingkungan, pengaruh jenis kelamin nyata untuk kedua metabolit urea serum dan kreatinine serum nilai yang tertinggi pada kambing umur 2.5-4 tahun. Hal ini menunjukkan bahwa suhu ekstrim dapat merangsang hati ternak dari kedua jenis kelamin dan semua kelompok umur terjadi peningkatan aktivitas metabolit (Kour, et al. 2014).

\section{KESIMPULAN DAN SARAN}

Hasil penelitian dan pembahasan dapat ditarik kesimpulan bahwa pemberian pakan suplemen UMMB dapat meningkatkan pertambahan berat badan induk bunting. Waktu yang optimum pemberian pakan suplemen pada induk bunting memberikan pertambahan berat badan yang tinggi pada umur kebuntingan 1 sampai 3 bulan (awal). Kandungan glukosa darah dipengaruhi oleh jenis kambing dan umur kebuntingan. Kandungan glukosa darah tinggi pada induk yang diberi pakan suplemen selama kebuntingan tetapi tidak berbeda pada kebuntingan awal dan akhir. Kandungan metabolit darah (urea dan kreatinine) tidak dipengaruhi oleh umur kebuntingan, dan kandungan metabolit darah relatif lebih tinggi pada ternak yang diberi pakan suplemen.

\section{DAFTAR PUSTAKA}

Abdel-Ghani, A.A., Solouma, M.A., Abd. Elmory, A.K.I., Kassab. A.Y., and Soliman, E.B. 2011. Productive Performance and Blood Metabolites as Affected by Protected in Sheep. Vol.1, No.2, 24-32 Open Jounal of Animal Science Openly accessible at http://www.scirp.org/journal/OJS

Addah, W and Karikari, P.K. . 2008. Effects of Dietary Restrictions during Different Stages of Pregnancy on Differential Plasma Protein Concetration, Placental and Birth Weight of Adolescent Djallonke Sheep. Livestock Research for Rural Development 20 (9) 2008

Ashworth, $\quad$ C.J., $\quad$ Dwyer,C.M., McEvoy,T.G., Rooke, J.A and Robinson, J.J. 2009. Thelimpact of In Utero Nutritional Programming on Small Ruminant Performances. Zaragoza: CIHEAM / FAO / NAGREF. Options Méditerranéennes: Série A. Séminaires Méditerranéens; $n .85$ 2009 pages 337- 349

Barakat, M.Z and El-Guindi, M.M. 2010. Relationship Between Nutritionally Related Blood Metabolites and Gastrointestinal Parasites in Nguni Goats of South Africa. Wiley Online Library.

Bulent Ellitok. 2012. Reference Values for Hematological and Biochemical Parameters in Saanen Goats Breeding in Afyonkarahisar Province Kocatepe. Vet. Journal 5 (1): $7-11$ 
Caton, J. S. and Hess, B.W. 2010. Maternal Plane of Nutrition: Impacts on Fetal Outcomes and Postnatal Offspring Responses. Invited Review. Pages 104-122 in Proc. 4th Grazing Livestock Nutrition Conference Department of Animal Sciences, 185 Hultz Hall, North Dakota State University

Celi, P., Adriana, D., Trana, C, Salvatore and Gregorio, P.D. 2008. Effects of Perinatal Nutrition on Metabolic and Hormonal Profiles of Goat Kids (Capra hircus) during Their First Day of Life .Asian-Aust. J. Anim. Sci. Vol. 21, No. 11 : 1585 $-1591$

De Campeneere, S., Fiems, L.,Vanacker, and J.Boucque. 2000. Evaluation of Urinary Creatine to ewstimate in Vivo Body Coposition of Belgian Blue Double-Muscle Bills. Ann. Zootech. 49:335-342

Du, M.., Tong, J., Zhao, J., Underwood, K.R., Zhu, M., Ford, S.P and P. Nathanielsz, P.W. 2009. Fetal Programming of Skeletal Muscle Development in Ruminant Animals. J Anim. SCI published online.

Fachiroh, L., Prasetiyono dan Subrata, A. 2012. Kadar Protein dan Urea Darah kambing Perah Peranakan Etawa yang diberi wafer Pakan Komplit Berbasis Limbah Agroindustri dengan Suplementasi protein Terproteksi. Fakultas Peternakan dan Pertanian Universitas Diponegoro.

Gao, F., Hou, X.Z., Liu, Y.C., Wu, S.Q and Ao, C.J. 2008. Effect of Maternal Under-Nutrition During Late Pregnancy on Lamb Birth Weight. Asian-Aust. J. Anim. Sci. 21:371-375.

Gottam, G.S., Kataria, N., Kataria, K.A., and Singh, L. 2005. Sewrum Metabolic Profile of Goats During
Stress. Veterinary Practtionar, 5(2) 2005, 156-158.

Haenien, G.F.W. 2006. Feeding Goats For Improved Milk Mlk and Meat Production - Goats and Nutrition. http/www/goatworld.com diakses 16 Pebruari 2006.

Hammond, A.C. 1998. Use of BUN and MUN as Guides for Protein and Energy Supplementation on Cattle. USDA, ARS, Subtropical Agricultural Research Station Roosville (Florida), 34601-4672 USA

Irkham Widiyono dan Samin. 2011. Profil Beberpa Parameter Kimia Darah Pada Kambing Peranakan ettawa. Database Jurnal Ilmiah Indonesia. ISJD LIPI.

Irkham Widiyono, Samin dan Bambang Suwignyo. 2013. Respons Metabolik Terhadap Pembatasan asupan Pakan pada Kambing Peranakan Ettawa. Jurnal Veteriner Vol. 14 No. 4:424-429.

Kour, G., Nalini Kataria and Ninad Sahebrao Lawhale. 2014. Ambient Temperature Associated Variation in Serum Urea and Creatinine. in Marwari Goats. IOSR Journal of agriculture and Veterinary Science (IOSR-JAVS): volume 7, Issue 3 Ver.I, 15-18 www.iosjournal.org

Laporte-Broux, B., Roussel, S., Ponter, A.A., Perault, J., Chavatte-Palmer, $\mathrm{P}$ and Duvaux-Ponter, C. 2011. Short-term Effect of Maternal Feed Restriction During Pregnancyon Goat Kid Morphology, Metabolism and behavior. J. Anim. Sci. 89:2154-2163.

Manu, E.A. 2007. Suplementasi Pakan Lokal Urea Gula Air Multinutrien Blok Untuk Meningkatkan Kinerja Induk Bunting dan Menyusui Serta Menekan Kematian Anak kambing blingon yang digembalakkan di sabana Timor. Disertasi Sekolah 
pascasarjana, Program studi ilmu Peternakan, Fakultas Peternakan Gajahmada, Yogyakarta

Murniati. T., Idrus, M., Tolleng, A.L. dan Raharja, D.P. 2011-2012. Waktu Suplementasi Pakan Yang Optimal Guna meningkatkan Efisiensi Reproduksi dan Genetik Kambing Peranakan Etawa (PE) . Laporan Hibah Pekerti DIKTI.

Murniati. T., Idrus, M., Tolleng, A.L. dan Raharja, D.P., Ako, A and Jussof, K. 2013. Optimalization of supplementasion Time for Improving Reproductive Effeciency and gene Expression of Goats. World Applied Sciences Journal 26 (Natural Resources Research and Development in Sulawesi Indonesia): 100-104.

Pazzola, M., Maria, L.D., Carcangiu, V., Luridiana, S and Maria. 2011. Relationship Milk Urea, Blood, Plasma Urea and Body Condition Score in Primiparaous Browsing Goats With Different Milk Yeild Level. Archiv Tierzucht 54, 5, 546556, Leibniz Institute for Farm Animal Biology, Dummerstorf, Germany.

Paulus, K., Tahuk, Barliati, E dan Hatadi, D. 2008. Keseimbangan Nitrogen dan Kandungan urea Darah kambing Blingon pada Penggemukkan dengan Level Protein Pakan Berbeda. J.Indon.Trop.Anim.agri 33(4) December 2008.

Rahadja, P.D. 2014. Menggas Program Prenatal Development Pada sapi Bali Sebagai Pedaging andalam dalam Mewujudkan Swasembada Daging Nasional. Disampaikan pada Upacara Penerimaan Guru Besar Fakultas Peternakan Universitas Hasanuddin.

Rehfeldt, C., Neil, C., Stickland., Ilse Fiedler., and Jochen Wegner. 1999
Environmental and Genetic Factors as Sources of Variation in Skeletal Muscle Fibre Number. Basic Appl. Myol. 9 (5): 235-253.

Raj Bindari, Y., Sherestha, S., Sheresthe, $\mathrm{N}$ and NathGaire, T. 2013. Effect of Nutrition on Reproduction. A Review Advance in Applied Science Research 4(1):421-429. Avaible online at www.pelagiaresearchlibrary.com

Sharma, A.K and Puri, G. 2013. EWffect of Extreme Hot Condition on serum Biochemical Constituens in Mawari Goats. Livestock ResearchInternational JulySeptember 2013, $4 t$ (1):421-429. Avaible online at www.pelagiaressearchlibrary.com

Van Saun, R.J. 2013. Feeding the Pregnant Feeding the Pregnant Doe: Understanding the Need for Supplements, Minerals and Vitamins. Extension Department of Veterinary Science Penn State University diakses 2013.

Vonnahme, K.A. 2007. Nutrition during gestation and fetal programming nutrition. Proceedings, The Range Beef Cow Symposium XX December 11, 12 and 13, 2007 Fort Collins, Colorado

Wu, G., Bazer, F.W., Cudd, T.A., Melninger, C.J and Spencer, T.E. 2004. Maternal Nutrion and Fetal Development. J. Nutr. 134:21692172.

$\mathrm{Xu}, \quad \mathrm{Y}^{*}$ Zhu, J., Dodson, M.V., Min, D. 2012. Developmental Programming of Fetal Skeletal Muscle and Adipose Tissue Development. $J$ Genomics 1:29-38 